\title{
ANALISIS AKUNTANSI PERTANGGUNGJAWABAN DALAM PENILAIAN KINERJA PADA KOPERASI PEGAWAI REPUBLIK INDONESIA SEMPULUR, KABUPATEN MAGELANG
}

\author{
Didik Muhamad Arif \\ Moch. Imron
}

\begin{abstract}
The purpose of this study is to find the application of accounting accountability in performance evaluation of based on the regulation of health assessment cooperativesf. Aspects assessment health cooperatives that used in the capital are aspects, management aspects of, aspects growth and independence. The data used in research it will be reports on the results of members meetings annual from 2012 until the year of 2014.metoda used an author in this research is method descriptive. The research results show that the implementation of accounting accountability in performance evaluation of based on the regulation cooperatives and smes minister no.14 2009 on the capital 2012 categorized good criteria healthy weight value 35,91 34,28-42,85, 2013 categorized pretty good with criteria pretty healthy value 30,78bobot 25,71-34,28dan in 2014 categorized good criteria sehatnilai 34,28 34,28-42,85 weight.Performance evaluation of management aspects of in 2012 and last until 2014 categorized good criteria healthy weight value 34,98 $34,28-42,85$. While assessment performance aspects independence and growth in 2012 categorized not very nice criteria were very unhealthy value $6.24 \quad 0-8,57$ weight.In 2013 and 2014 categorized less than good criteria unhealthy value 23,54 with weights 17,14-25,71.
\end{abstract}

Keyword: accounting accountability, performance assessment, health assessment cooperatives.

\section{PENDAHULUAN}

Era Masyarakat Ekonomi ASEAN (MEA) pada tahun 2015 membawa suatu peluang sekaligus tantangan bagi ekonomi Indonesia. Dengan diberlakukanya kerja sama antar MEA, maka akan mengalami aliran bebas barang, investasi dan tenaga kerja dari masing-masing negara di ASEAN. Demikian pula akan berpengaruh pada pertumbuhan dan perkembangan ekonomi (www.antaranews.com). Menghadapi era pasar bebas se-Asia Tenggara, dunia usaha di Indonesia tentu harus membuat strategi untuk menghadapi persaingan. Tidak terkecuali di sektor koperasi dan usaha kecil menengah.

Kementerian Koperasi dan UKM telah menyusun langkah-langkah antisipasi untuk membantu pelaku koperasi dan usaha kecil menengah dalam menghadapi era 
pasar bebas. Pemerintah sangat memperhatikan perkembangan Koperasi Indonesia karena organisasi usaha ini mampu meningkatkan pertumbuhan ekonomi, membuka lapangan pekerjaan baru, menurunkan tingkat kemiskinan dan meningkatkan kemakmuran rakyat. Perkembangan koperasi disalah satu provinsi di Indonesia yaitu Jawa Tengah tidak luput dari pengawasan Kementerian Koperasi, dengan mendapatkan berbagai penghargaan di antaranya penghargaan Satyalancana Pembangunan atas jasanya memajukan pembangunan koperasi dan UMKM yang diserahkan Presiden Susilo Bambang Yudhoyono kepada Gubernur Jawa Tengah Ganjar Pranowo dalam Peringatan Hari Koperasi Tingkat Nasional ke-67 tahun 2014, di Lapangan Benteng Kota Medan Sumatra Utara (Suara Merdeka, 15 Juli 2014).

Adanya upaya-upaya yang dilakukan untuk meningkatkan kemampuan koperasi maka diperlukan adanya sistem penilaian kinerja. Penilaian kinerja dapat diartikan sebagai alat untuk menilai seberapa besar hasil yang telah diperoleh dari kegiatan yang telah dilakukan oleh unit kerja. Penilaian kinerja koperasi berpedoman pada Peraturan Menteri Koperasi dan UKM Nomor 14 Tahun 2009 tentang penilaian kesehatan koperasi. Penilaian kesehatan koperasi meliputi beberapa aspek antara lain aspek permodalan, kualitas aktiva produktif, manajemen, efisiensi, kemandirian dan pertumbuhan, likuiditas dan jati diri koperasi. Berdasar hasil penilaian yang dilakukan maka kondisi kesehatan koperasi bisa dinyatakan sehat, cukup sehat, kurang sehat, tidak sehat dan sangat tidak sehat.

Kinerja sangat dipengaruhi oleh baik atau tidaknya perencanaan dan sistem pengendalian manajemen yang diterapkan dalam menjalankan kegiatan operasional koperasi. Aspek-aspek dalam penilaian kesehatan koperasi terdapat komponen yang mendominasi dan menjadi tolok ukur berhasil atau tidaknya kinerja yang telah dilakukan. Mengingat manajemen koperasi dilakukan secara terbuka sehingga semua anggota koperasi bisa terlibat dalam merencanakan kegiatan maka akuntansi pertanggungjawaban sangat penting diterapkan untuk mengontrol semua kegiatan yang telah direncanakan.

Penelitian terdahulu yang dilakukan oleh Lilik (2013) mengenai analisis laporan keuangan dalam menilai kinerja keuangan pada Primer Koperasi Angkatan 
Darat Kartika Benteng Sejahtera di Balikpapan menunjukkan hasil bahwa kriteria standar penilaian koperasi berprestasi yang ditinjau dari rasio likuiditas dan rasio profitabilitas, dapat dikatakan bahwa koperasi yang berprestasi. Sedangkan ditinjau dari rasio solvabilitas dan rasio aktivitas, koperasi dianggap tidak berprestasi. Hasil penelitian Misbachul dan Iin (2012) menyebutkan bahwa tingkat kesehatan koperasi simpan pinjam dengan aspek permodalan, kualitas aktiva produktif, efisiensi, kemandirian dan pertumbuhan, likuiditas dan jati diri koperasi, mendapat predikat cukup sehat.

Beberapa penelitian yang telah dilakukan hanya menganalisis kesehatan koperasi dan masih berpedoman pada Peraturan Menteri Koperasi dan UKM Nomor 20 Tahun 2008. Sedangkan Dinas Koperasi dan UKM saat ini menggunakan Peraturan Menteri Koperasi dan UKM Nomor 14 Tahun 2009 sebagai pedoman menilai kesehatan koperasi. Kinerja sangat dipengaruhi oleh bagus atau tidaknya perencanaan dan sistem pengendalian manajemen yang diterapkan dalam menjalankan kegiatan operasional koperasi. Aspek-aspek dalam penilaian kesehatan koperasi terdapat komponen yang mendominasi dan menjadi tolok ukur berhasil atau tidaknya kinerja yang telah dilakukan.

Melihat permasalahan yang telah diuraikan sebelumnya, maka penelitian ini akan menganalisis penerapan akuntansi pertanggungjawaban yang digunakan untuk menilai kinerja pada koperasi sesuai dengan Peraturan Menteri Koperasi dan UKM Nomor 14 Tahun 2009 tentang pedoman penilaian kesehatan koperasi. Berdasarkan pemikiran ini maka penulis akan meneliti mengenai analisis akuntansi pertanggungjawaban dalam penilaian kinerja pada koperasi pegawai Republik Sempulur Kabupaten Magelang.

\section{TINJAUAN PUSTAKA}

\section{Sistem Akuntansi Pertanggungjawaban}

Sistem akuntansi pertanggungjawaban merupakan sistem pengukuran keuangan yang mencatat rencana-rencana dan kinerja menurut variabel-variabel keuangan, terhadap manajer bertanggungjawab (Hansen dan Mowen 2009: 229). Sistem akuntansi pertanggungjawaban dipakai untuk menghimpun informasi kinerja berdasarkan segmen dan melaporkan hasil-hasil dari manajer-manajer yang 
bertanggungjawab. Oleh karena itu, sistem akuntansi pertanggungjawaban harus disesuaikan dengan kebutuhan-kebutuhan spesifik dan kondisi operasi perusahaan sehingga pelaporan kinerja semua pos finansial yang dipertimbangkan bisa dicapai oleh pusat-pusat pertanggungjawaban di dalam organisasi. Sistem ini tidak sekedar menghendaki bahwa organisasi dapat mencapai tujuannya dengan memperoleh pendapatan sesuai dengan yang dianggarkan, tetapi dapat juga digunakan untuk mengukur prestasi kerja setiap pusat pertanggungjawaban.

\section{Akuntansi Pertanggungjawaban}

Akuntansi pertanggungjawaban adalah alat fundamental untuk pengendalian manajemen dan ditentukan melalui empat elemen penting, yaitu pemberian tanggungjawab, pembuatan ukuran kinerja, pengevaluasian kinerja, dan pemberian penghargaan. Akuntansi pertanggungjawaban bertujuan mempengaruhi perilaku dalam cara tertentu sehingga seseorang atau kegiatan perusahaan akan disesuaikan untuk mencapai tujuan bersama (Hansen dan Mowen, 2009: 229). Akuntansi pertanggungjawaban adalah suatu sistem akuntansi yang disusun sedemikian rupa sehingga pengumpulan serta pelaporan biaya dan pendapatan dilakukan sesuai dengan pusat pertanggungjawaban dalam organisasi, dengan tujuan agar dapat ditunjuk orang atau kelompok orang yang bertanggungjawab atas penyimpangan biaya dan atau pendapatan yang dianggarkan (Mulyadi, 2004: 188).

\section{Pusat Pertanggungjawaban}

Pusat pertanggungjawaban dapat diartikan sebagai unit kerja dalam organisasi yang dipimpin oleh seorang manajer yang bertanggungjawab atas kegiatan-kegiatan dalam unit kerjanya. Pusat pertanggungjawaban pada dasarnya dibentuk untuk mencapai suatu sasaran tertentu (Sumarsan, 2010:85). Menurut Anthony dan Govindarajan (2009:171) pusat pertanggungjawaban adalah organisasi yang dipimpin oleh seorang manajer yang bertanggungjawab terhadap aktifitas yang dilakukan. 


\section{Pengertian dan Karakteristik Koperasi}

Koperasi di lingkungan badan usaha beranggotakan orang-orang yang melakukan usaha bersama yang didasarkan atas asas kekeluargaan. Kegiatan koperasi dilakukan sekelompok orang yang bekerjasama untuk menggunakan output-output ekonomi dari badan usaha untuk tercapainya tujuan, yaitu meningkatkan kesejahteraan anggota. Menurut Ikatan Akuntan Indonesia (IAI) dalam Pernyataan Standar Akuntansi Keuangan No. 27 (2009: 27), pengertian koperasi adalah badan usaha yang mengorganisir pemanfataan dan pendayagunaan sumber daya ekonomi para anggotanya atas dasar prinsip - prinsip koperasi pada kaidah ekonomi untuk meningkatkan taraf hidup anggota pada khususnya dan masyarakat daerah kerja pada umumnya, dengan demikian koperasi merupakan gerakan ekonomi rakyat dan sokoguru perekonomian nasional.

\section{Koperasi Simpan Pinjam}

Koperasi simpan pinjam merupakan lembaga koperasi yang melakukan kegiatan usaha penghimpunan dan penyaluran dana dari dan untuk anggota, calon anggota, koperasi lain, dan atau anggotanya, yang perlu dikelola secara profesional sesuai dengan prinsip kehati-hatian dan kesehatan koperasi simpan pinjam, sehingga dapat meningkatkan kepercayaan dan memberikan manfaaat yang sebesar-besarnya kepada anggota dan masyarakatnya (Peraturan Menteri Koperasi dan UKM Nomor 14 Tahun 2009). Koperasi Simpan Pinjam mempunyai peluang tumbuh dan berkembang yang sangat baik dalam kegiatan usahanya. Peningkatan kebutuhan anggota dan masyarakat pada setiap tahun menjadi alasan penting bagi Koperasi Simpan Pinjam untuk meningkatkan kegiatan usahanya. Kualitas pelayanan dan manajemen yang baik menjadi faktor utama koperasi simpan pinjam dalam mengembangkan usahanya.

\section{Penilaian Kinerja}

Menurut Sukarno (2008: 207) penilaian kinerja adalah kegiatan untuk menilai kesuksesan atau kegagalan suatu pusat pertanggungjawaban atau unit kerja dalam melaksanakan tugas dan fungsi yang diembannya. Menurut Simanjuntak (2011: 154) penilaian kinerja yang ideal adalah penilaian yang dilakukan oleh atasan 
langsung, penilaian yang dilakukan oleh diri sendiri, penilaian yang dilakukan oleh tim penilai khusus, dan penilaian yang dilakukan oleh pihak terkait seperti pelanggan, bawahan ataupun teman sekerja.

Pedoman yang digunakan koperasi dalam penilaian kinerja mengacu pada Peraturan Menteri Negara Koperasi dan Usaha Kecil dan Menengah Republik Indonesia Nomor 14 Tahun 2009, tentang pedoman penilaian kesehatan koperasi simpan pinjam dan unit kopersi simpan pinjam. Ruang lingkup tersebut meliputi:

a. Ruang lingkup Penilaian Kesehatan KSP dan USP Koperasi meliputi penilaian terhadap beberapa aspek diantaranya permodalan, kualitas aktiva produktif, manajemen, efisiensi, likuiditas, kemandirian, dan pertumbuhan, serta jatidiri koperasi.

b. Penilaian aspek permodalan dalam koperasi simpan pinjam meliputi rasio modal sendiri terhadap total aset, rasio modal sendiri terhadap pinjaman yang berisiko, dan rasio kecukupan modal sendiri.

c. Penilaian aspek kualitas aktiva produktif dalam koperasi simpan pinjam meliputi rasio volume pinjaman pada anggota terhadap volume pinjaman diberikan, rasio risiko pinjaman bermasalah terhadap pinjaman yang diberikan, rasio cadangan risiko terhadap pinjaman bermasalah, dan rasio pinjaman yang berisiko terhadap pinjaman yang diberikan.

d. Penilaian aspek manajemen dalam koperasi simpan pinjam meliputi manajemen aktiva, dan manajemen likuiditas.

e. Penilaian aspek efisiensi dalam koperasi simpan pinjam meliputi rasio beban operasi anggota terhadap partisipasi bruto, rasio beban usaha terhadap SHU kotor, dan rasio efisiensi pelayanan.

f. Penilaian aspek likuiditas dalam koperasi simpan pinjam meliputi rasio kas dan rasio pinjaman yang diberikan terhadap dana yang diterima.

g. Penilaian aspek kemandirian dan pertumbuhan dalam koperasi simpan pinjam meliputi rentabilitas aset, rentabilitas modal sendiri, dan kemandirian operasional pelayanan. 


\section{METODA PENELITIAN}

\section{Objek Penelitian}

Objek penelitian ini adalah Koperasi Pegawai Republik Indonesia Sempulur di Kabupaten Magelang. Koperasi ini merupakan jenis koperasi unit simpan pinjam.Variabel penelitian ini adalah akuntansi pertanggungjawaban yang diterapkan untuk menilai kinerja berdasarkan penilaian kesehatan koperasi pada Koperasi Pegawai Republik Indonesia Sempulur di Kabupaten Magelang.

\section{Jenis Data dan Sumber Data}

Jenis data yang dikumpulkan dalam penelitian ini adalah data kualitatif dan data kuantitatif. Data kualitatif pada penelitian ini adalah data yang berasal dari opini subjek yang diperoleh dari hasil wawancara. Data primer dalam penelitian ini adalah hasil wawancara yang dilakukan dengan anggota yang menjabat sebagai manajer keuangan pada KPRI Sempulur. Data sekunder yang digunakan adalah literaturliteratur, jurnal, serta artikel yang dibuat oleh pihak ketiga dan mempunyai relevansi dengan penelitian ini.

\section{Teknik Analisis Data}

Analisis data yang dilakukan dalam penelitian ini adalah dengan metoda deskriptif. Teknik analisis yang digunakan dalam penelitian ini yaitu menganalisis aspek-aspek dalam ruang lingkup penilaian kesehatan koperasi yang mengacu pada Peraturan Menteri Koperasi dan UKM Nomor 14 Tahun 2009. Penilaian aspek dilakukan dengan menggunakan nilai yang dinyatakan dalam angka 0 sampai dengan 100. Namun berkaitan dengan aspek yang dianalisis dalam penelitian ini hanya tiga dari tujuh aspek maka penilaian dinyatakan dalam angka 0 sampai dengan 42,85. Bobot penilaian terhadap aspek dan komponen tersebut ditetapkan sebagai berikut:

\section{Permodalan}

a. Rasio modal sendiri terhadap total aset

Untuk memperoleh rasio antara modal sendiri terhadap total aset ditetapkan sebagai berikut:

1) Untuk rasio antara modal sendiri dengan total aset lebih kecil atau sama dengan $0 \%$ diberikan nilai 0 . 
2) Untuk setiap kenaikan rasio $4 \%$ mulai dari $0 \%$ nilai ditambah 5 dengan maksimum nilai 100 .

3) Untuk rasio lebih besar dari $60 \%$ sampai rasio $100 \%$ setiap kenaikan rasio $4 \%$ nilai dikurangi 5.

4) Nilai dikalikan bobot sebesar $6 \%$ diperoleh skor permodalan.

b. Rasio modal sendiri terhadap pinjaman diberikan yang berisiko. Untuk memperoleh rasio modal sendiri terhadap pinjaman diberikan yang berisiko, ditetapkan sebagai berikut:

1) Untuk rasio modal sendiri terhadap pinjaman diberikan yang berisiko lebih kecil atau sama dengan $0 \%$ diberi nilai 0 .

2) Untuk setiap kenaikan rasio $1 \%$ mulai dari $0 \%$ nilai ditambah 1 dengan nilai maksimum 100 .

3) Nilai dikalikan bobot sebesar 6\%, maka diperoleh skor permodalan.

c. Rasio kecukupan modal sendiri

1) Rasio kecukupan modal sendiri yaitu perbandingan antara modal sendiri tertimbang dengan aktiva tertimbang menurut risiko (ATMR) dikalikan dengan $100 \%$.

2) Modal tertimbang adalah jumlah dari hasil kali setiap komponen modal KSP/USP koperasi yang terdapat pada neraca dengan bobot pengakuan risiko.

3) ATMR adalah jumlah dari hasil kali setiap komponen aktiva KSP dan USP Koperasi yang terdapat pada neraca dengan bobot pengakuan risiko.

4) Menghitung nilai ATMR dilakukan dengan cara menjumlahkan hasil perkalian nilai nominal aktiva yang ada dalam neraca dengan bobot risiko masing-masing komponen aktiva.

5) Rasio kecukupan modal sendiri dapat dihitung/diperoleh dengan cara membandingkan nilai modal tertimbang dengan nilai ATMR.

6) Dikalikan dengan $100 \%$. 


\section{Penilaian manajemen}

Penilaian aspek manajemen KSP dan USP koperasi dalam penelitian ini meliputi komponen sebagai berikut:

a. Manajemen aktiva

b. Manajemen likuiditas

Perhitungan nilai didasarkan kepada hasil penilaian atas jawaban pertanyaan aspek manajemen terhadap seluruh komponen dengan komposisi pertanyaan sebagai berikut (pertanyaan terlampir):

a. Manajemen aktiva 6 pertanyaan (bobot 3 atau 0,5 nilai untuk setiap jawaban pertanyaan "ya").

b. Manajemen likuiditas 5 pertanyaan (bobot 3 atau 0,6 nilai untuk setiap jawaban pertanyaan "ya").

Adapun daftar penilaian aspek manajemen aktiva dan aspek manajemen likuiditas sebagai berikut:

a. Manajemen Aktiva

1) Pinjaman dengan kolektibilitas lancar minimal sebesar $90 \%$ dari pinjaman yang diberikan (dibuktikan dengan laporan pengembalian pinjaman).

2) Setiap pinjaman yang diberikan didukung dengan agunan yang nilainya sama atau lebih besar dari pinjaman yang diberikan kecuali pinjaman bagi anggota sampai dengan 1 juta rupiah (dibuktikan dengan laporan pinjaman dan daftar agunannya).

3) Dana cadangan penghapusan pinjaman sama atau lebih besar dari jumlah pinjaman macet tahunan (dibuktikan dengan laporan kolektibilitas pinjaman dan cadangan penghapusan pinjaman).

4) Keputusan pemberian pinjaman dan atau penempatan dana dilakukan melalui komite (dibuktikan dengan risalah rapat komite).

5) Setelah pinjaman diberikan KSP/USP Koperasi melakukan pemantauan terhadap penggunaan pinjaman serta kemampuan dan kepatuhan anggota atau peminjam dalam memenuhi kewajibannya (dibuktikan dengan laporan monitoring). 
6) KSP/USP Koperasi melakukan peninjauan, penilaian dan pengikatan terhadap agunannya (dibuktikan dengan dokumen pengikatan dan atau penyerahan agunan).

b. Manajemen Likuiditas

1) Memiliki kebijaksanaan tertulis mengenai pengendalian likuiditas (dibuktikan dengan dokumen tertulis mengenai perencanaan usaha).

2) Memiliki fasilitas pinjaman yang akan diterima dari lembaga lain untuk menjaga likuiditasnya (dibuktikan dengan dokumen tertulis mengenai kerjasama pendanaan dari lembaga keuangan lainnya).

3) Memiliki pedoman administrasi yang efektif untuk memantau kewajiban yang jatuh tempo (dibuktikan dengan adanya dokumen tertulis mengenai skedul penghimpunan simpanan dan pemberian pinjaman).

4) Memiliki kebijakan penghimpunan simpanan dan pemberian pinjaman sesuai dengan kondisi keuangan KSP/USP koperasi (dibuktikan dengan kebijakan tertulis).

5) Memiliki sistem informasi manajemen yang memadai untuk pemantauan likuiditas (dibuktikan dengan dokumen tertulis berupa sistem pelaporan penghimpunan simpanan dan pemberian pinjaman).

\section{Kemandirian dan Pertumbuhan}

Penilaian terhadap kemandirian dan pertumbuhan didasarkan pada tiga rasio, yaitu rentabilitas aset, rentabilitas ekuitas, dan kemandirian operasional.

a. Rasio rentabilitas aset

Rasio rentabilitas aset yaitu SHU sebelum pajak dibandingkan dengan total aset, perhitungannya ditetapkan sebagai berikut:

1) Untuk rasio rentabilitas aset lebih kecil dari $5 \%$ diberi nilai 25 , untuk setiap kenaikan rasio 2,5\% nilai ditambah 25 sampai dengan maksimum100.

2) Nilai dikalikan dengan bobot $3 \%$ diperoleh skor penilaian.

b. Rasio rentabilitas modal sendiri

Rasio rentabilitas modal sendiri yaitu SHU bagian anggota dibandingkan total modal sendiri, perhitungannya ditetapkan sebagai berikut: 
1) Untuk rasio rentabilitas modal sendiri lebih kecil dari $3 \%$ diberi nilai 25 , untuk setiap kenaikan rasio $1 \%$ nilai ditambah 25 sampai dengan maksimum 100.

2) Nilai dikalikan dengan bobot $3 \%$ diperoleh skor penilaian.

c. Rasio kemandirian operasional pelayanan

Rasio kemandirian operasional yaitu partisipasi netto dibandingkan beban usaha ditambah beban perkoperasian, perhitungannya ditetapkan sebagaiberikut:

a. Untuk rasio kemandirian operasional lebih kecil atau sama dengan $100 \%$ diberi nilai 0, dan untuk rasio lebih besar dari 100\% diberi nilai 100 .

b. Nilai dikalikan dengan bobot $4 \%$ diperoleh skor penilaian.

Tabel 1

Petunjuk Pelaksanaan Penilaian Kesehatan Koperasi

\begin{tabular}{|c|c|c|c|c|}
\hline \multirow{2}{*}{$\begin{array}{l}\text { No } \\
1\end{array}$} & $\begin{array}{l}\text { Aspek yang } \\
\text { Dinilai }\end{array}$ & Komponen & \multicolumn{2}{|c|}{$\begin{array}{c}\text { Bobot } \\
\text { Penilaian }\end{array}$} \\
\hline & \multicolumn{2}{|l|}{ Permodalan } & Skor & 15 \\
\hline & & $\begin{array}{l}\text { a. Rasio Modal Sendiri Terhadap Total Aset } \\
\frac{\text { Modal sendiri }}{\text { Total asset }} \text { x } 100 \% \\
\text { b. Rasio modal Sendiri terhadap Pinjaman Berisiko } \\
\frac{\text { Modal sendiri }}{\text { Pinjaman diberikan berisiko }} \times 100 \% \\
\text { c. Rasio Kecukupan Modal Sendiri } \\
\frac{\text { Modal sendiri tertimbang }}{\text { ATMR }} \times 100 \%\end{array}$ & $\begin{array}{l}6 \\
6\end{array}$ & \\
\hline \multirow[t]{2}{*}{2} & \multicolumn{2}{|l|}{ Manajemen } & & 6 \\
\hline & & $\begin{array}{l}\text { a. Manajemen aktiva } \\
\text { b. Manajemen likuiditas }\end{array}$ & $\begin{array}{l}3 \\
3\end{array}$ & \\
\hline \multirow[t]{3}{*}{3} & \multicolumn{2}{|c|}{ Kemandirian dan Pertumbuhan } & & 10 \\
\hline & & $\begin{array}{l}\text { a. Rentabilitas Aset } \\
\frac{\text { SHU sebelum pajak }}{\text { Total Aset }} \times 100 \%\end{array}$ & 3 & \\
\hline & & $\begin{array}{l}\text { b. Rentabilitas Modal Sendiri } \\
\text { SHU bagian anggota X } 100 \%\end{array}$ & 3 & \\
\hline
\end{tabular}




\begin{tabular}{|l|l|l|l|}
\hline & Total modal sendiri & & \\
\hline & $\begin{array}{c}\text { c. Kemandirian Operasional Pelayanan } \\
\frac{\text { Partisipasi neto }}{\text { Beban usaha + beban perkoperasian }}\end{array}$ & 4 & \\
\hline
\end{tabular}

Sumber: Peraturan Menteri Koperasi dan UKM Nomor 14 tahun 2009

Tabel 2

Standar Penilaian 7 Aspek Kesehatan Koperasi

\begin{tabular}{|c|c|c|}
\hline No & Bobot Nilai & Keterangan \\
\hline 1 & $80-100$ & Sehat \\
\hline 2 & $60-80$ & Cukup Sehat \\
\hline 3 & $40-60$ & Kurang Sehat \\
\hline 4 & $20-40$ & Tidak Sehat \\
\hline 5 & $0-20$ & Sangat Tidak Sehat \\
\hline
\end{tabular}

Sumber: Peraturan Menteri Koperasi dan UKM Nomor 14 Tahun 2009

\section{HASIL DAN PEMBAHASAN}

Berdasarkan hasil dari perhitungan pada aspek kesehatan KPRI Sempulur tahun 2012 sampai 2014. Langkah selanjutnya akan dihitung tingkat kesehatan koperasi secara keseluruhan untuk mengetahui predikat tingkat kesehatan koperasi Sempulur berdasarkan standar perhitungan yang telah ditetapkan dalam Peraturan Menteri Koperasi dan UKM Nomor 14 tahun 2009:

\section{Aspek Permodalan}

Tabel 3

Hasil Perhitungan Aspek Permodalan Tahun 2012

\begin{tabular}{|l|c|c|c|c|}
\hline \multicolumn{1}{|c|}{ Rasio } & Hasil & Nilai & Bobot & Skor \\
\hline Rasio Modal Sendiri terhadap Total Aset & $54,72 \%$ & 100 & 6 & 6 \\
\hline Rasio Modal Sendiri terhadap Pinjaman & $69,11 \%$ & 60 & 6 & 3,6 \\
\hline Rasio Kecukupan Modal Sendiri & $66,90 \%$ & 100 & 3 & 3 \\
\hline \multicolumn{2}{|c|}{ Total } & & 12,6 \\
\hline
\end{tabular}

Sumber: Data sekunder, diolah (2015) 
Jumlah bobot maksimal aspek permodalan adalah 15 poin dari total 42,85 poin, maka setiap 1 poin memperoleh skor 2,85 (lihat tabel 3.9). Hasil perhitungan menunjukkan poin yang diperoleh adalah 12,6 poin, jadi penilaian aspek permodalan memperoleh nilai 35,91 dengan predikat "Sehat".

\section{Tabel 4}

Hasil Perhitungan Aspek Permodalan Tahun 2013

\begin{tabular}{|l|c|c|c|c|}
\hline \multicolumn{1}{|c|}{ Rasio } & Hasil & Nilai & Bobot & Skor \\
\hline Rasio Modal Sendiri Terhadap Total Aset & $74,68 \%$ & 50 & 6 & 3 \\
\hline $\begin{array}{l}\text { Rasio modal Sendiri terhadap Pinjaman } \\
\text { berisiko }\end{array}$ & $85,98 \%$ & 60 & 6 & 4,8 \\
\hline Rasio Kecukupan Modal Sendiri & $84,54 \%$ & 100 & 3 & 3 \\
\hline \multicolumn{1}{|c|}{ Total } & & & 10,8 \\
\hline
\end{tabular}

Sumber: Data sekunder, diolah (2015)

Jumlah bobot maksimal aspek permodalan adalah 15 poin dari total 42,85 poin, maka setiap 1 poin memperoleh skor 2,85. Hasil perhitungan menunjukkan poin yang diperoleh adalah 10,8 poin, jadi penilaian aspek permodalan memperoleh nilai 30,78 dengan predikat "Cukup Sehat".

\section{Tabel 4}

Hasil Perhitungan Aspek Permodalan Tahun 2014

\begin{tabular}{|l|c|c|c|c|}
\hline \multicolumn{1}{|c|}{ Rasio } & Hasil & Nilai & Bobot & Skor \\
\hline Rasio Modal Sendiri Terhadap Total Aset & $69,22 \%$ & 50 & 6 & 3 \\
\hline $\begin{array}{l}\text { Rasio modal Sendiri terhadap Pinjaman } \\
\text { berisiko }\end{array}$ & $100,94 \%$ & 100 & 6 & 6 \\
\hline Rasio Kecukupan Modal Sendiri & $97,19 \%$ & 100 & 3 & 3 \\
\hline \multicolumn{2}{|c|}{ Total } & & 12 \\
\hline
\end{tabular}

Sumber: Data sekunder, diolah (2015)

Jumlah bobot maksimal aspek permodalan adalah 15 poin dari total 42,85 poin, maka setiap 1 poin memperoleh skor 2,85. Hasil perhitungan menunjukkan 
angka 12 poin, jadi penilaian aspek permodalan memperoleh nilai 34,28 dengan predikat "SEHAT".

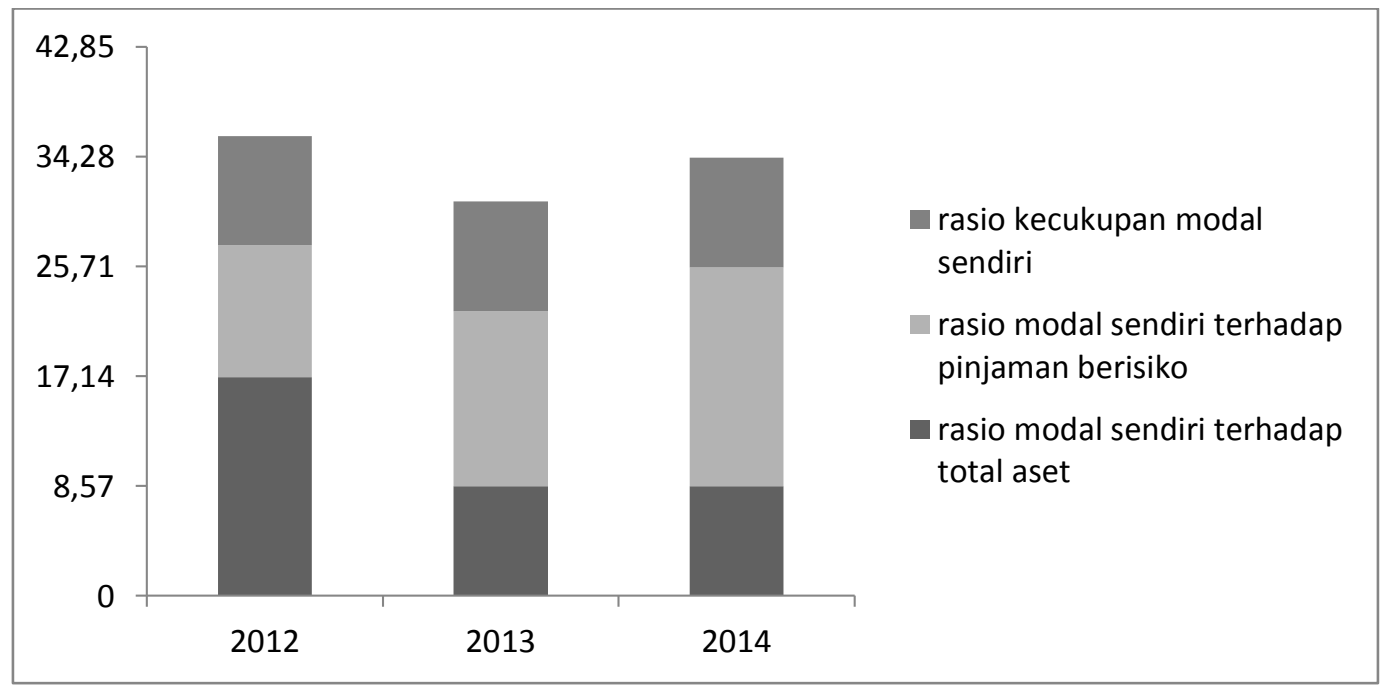

Sumber: Data sekunder, diolah (2015)

\section{Grafik 1}

\section{Aspek Permodalan Tahun 2012-2014}

Berdasar grafik 1 dapat dilihat aspek permodalan selama tiga tahun. Pada tahun 2012 memperoleh bobot nilai 35,91 dengan predikat sehat, tahun 2013 memperoleh bobot nilai 30,78 dengan predikat cukup sehat dan pada tahun 2014 memperoleh bobot nilai 34,28 dengan predikat sehat.

\section{Aspek Manajemen}

\section{Tabel 5}

Hasil Perhitungan Aspek Manajemen Tahun 2012-2014

\begin{tabular}{|l|c|c|}
\hline \multicolumn{1}{|c|}{ Rasio } & Hasil & Skor \\
\hline Manajemen Aktiva & 5 & 2,5 \\
\hline Manajemen Likuiditas & 4 & 2,4 \\
\hline
\end{tabular}

Sumber: Data sekunder, diolah (2015)

Jumlah bobot maksimal aspek manajemen adalah 6 poin dari total 42,85 poin, maka setiap 1 poin memperoleh skor 7,14. Hasil perhitungan tahun 2012-2014 memperoleh 4,9 poin, jadi penilaian aspek manajemen memperoleh nilai 34,98 dengan predikat "Sehat". 


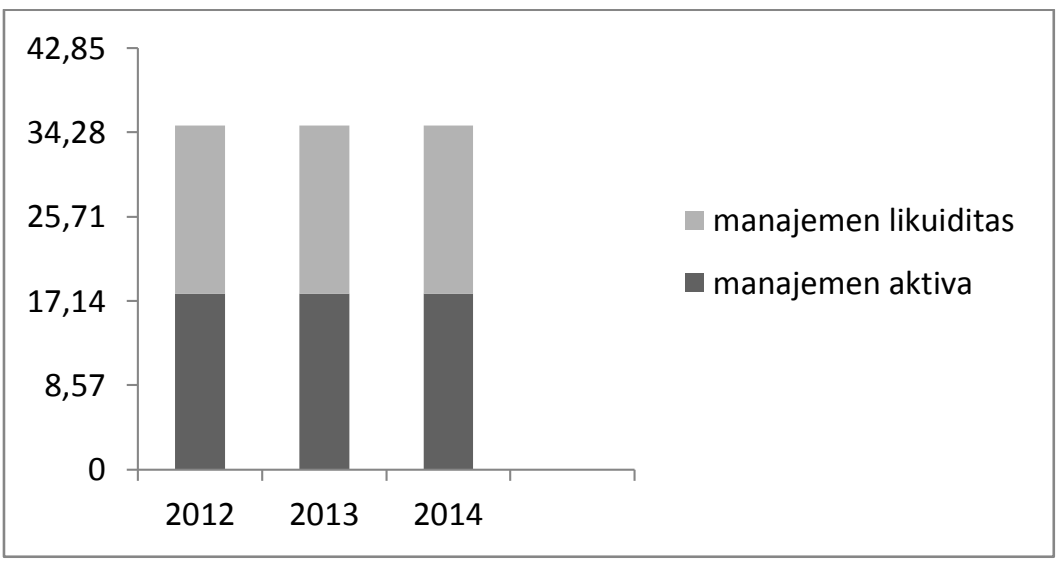

Sumber: Data sekunder, diolah (2015)

Grafik 2

Aspek Manajemen

Berdasar grafik 2 dapat dilihat aspek manajemen tahun 2012-2014. Grafik tersebut menunjukkan bahwa bobot nilai yang sama yaitu 34,98 dengan predikat sehat (lihat tabel 3.11 halaman 38).

\section{Aspek Kemandirian dan Pertumbuhan}

Tabel 6

Hasil Perhitungan Aspek Kemandirianda n Pertumbuhan Tahun 2012

\begin{tabular}{|l|c|c|c|c|}
\hline \multicolumn{1}{|c|}{ Rasio } & Hasil & Nilai & Bobot & Skor \\
\hline Rentabilitas aset & $1,04 \%$ & 25 & 3 & 0,75 \\
\hline Rentabilitas modal sendiri & $0,33 \%$ & 25 & 3 & 0,75 \\
\hline Kemandirian operasional pelayanan & $93,27 \%$ & 0 & 4 & 0 \\
\hline \multicolumn{2}{|c|}{ Total } & & 1,5 \\
\hline
\end{tabular}

Sumber: Data sekunder, diolah (2015)

Jumlah bobot aspek kemandirian dan pertumbuhan adalah 10 poin dari total 42,85 poin, maka setiap 1 poin memperoleh skor 4,28 (lihat tabel 3.9). Hasil perhitungan di atas memperoleh 1,5 poin, jadi penilaian aspek kemandirian dan pertumbuhan memperoleh nilai 6,42 dengan predikat " Sangat Tidak Sehat”. 
Tabel 7

Hasil Perhitungan Aspek Kemandirian dan Pertumbuhan Tahun 2013

\begin{tabular}{|l|c|c|c|c|}
\hline \multicolumn{1}{|c|}{ Rasio } & Hasil & Nilai & Bobot & Skor \\
\hline Rentabilitas asset & $0,77 \%$ & 25 & 3 & 0,75 \\
\hline Rentabilitas modal sendiri & $0,18 \%$ & 25 & 3 & 0,75 \\
\hline Kemandirian operasional pelayanan & $109,24 \%$ & 100 & 4 & 4 \\
\hline \multicolumn{2}{|c|}{ Total } & & 5,5 \\
\hline
\end{tabular}

Sumber: Data sekunder, diolah (2015)

Jumlah bobot aspek kemandirian dan pertumbuhan adalah 10 poin dari total 42,85 poin, maka setiap 1 poin memperoleh skor 4,28 (lihat tabel 3.9). Hasil perhitungan di atas memperoleh 5,5 poin, jadi penilaian aspek kemandirian dan pertumbuhan memperoleh nilai 23,54 dengan predikat " Kurang Sehat"(lihat tabel 3.11 halaman 38).

Tabel 8

Hasil Perhitungan Aspek Kemandirian dan Pertumbuhan Tahun 2014

\begin{tabular}{|l|c|c|c|c|}
\hline \multicolumn{1}{|c|}{ Rasio } & Hasil & Nilai & Bobot & Skor \\
\hline Rentabilitas aset & 1,27 & 25 & 3 & 0,75 \\
\hline Rentabilitas modal sendiri & 0,36 & 25 & 3 & 0,75 \\
\hline Kemandirian operasional pelayanan & $144,78 \%$ & 100 & 4 & 4 \\
\hline \multicolumn{2}{|r|}{ Total } & & 5,5 \\
\hline
\end{tabular}

Sumber: Data sekunder, diolah (2015)

Jumlah bobot maksimal aspek kemandirian dan pertumbuhan adalah 10 poin dari total 42,85 poin, maka setiap 1 poin memperoleh skor 4,28 (lihat tabel 3.9). Hasil perhitungan di atas memperoleh 5,5 poin, jadi penilaian aspek kemandirian dan pertumbuhan memperoleh nilai 23,54 dengan predikat "Kurang Sehat". 


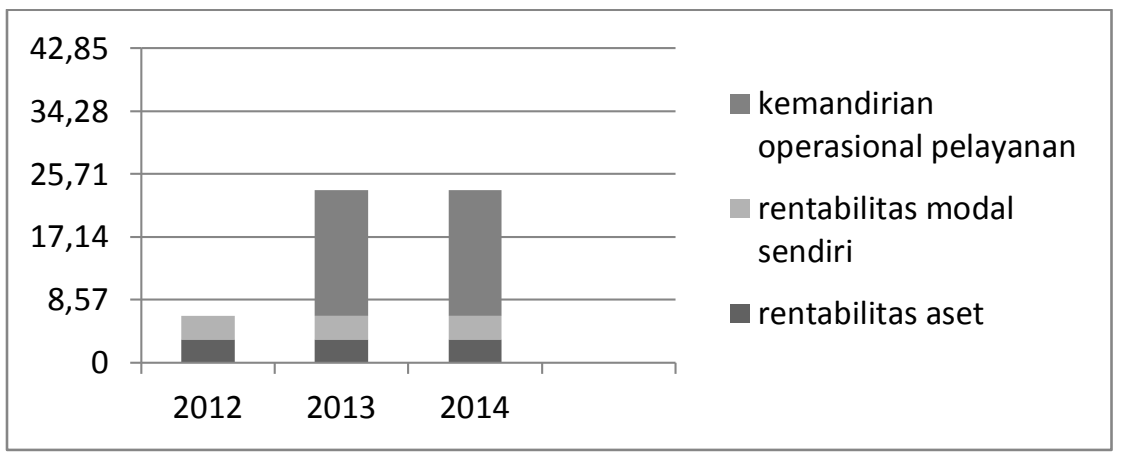

Sumber: Data sekunder, diolah (2015)

\section{Grafik 3}

\section{Aspek Manajemen Kemandirian dan Pertumbuhan}

Berdasar grafik 3 dapat dilihat aspek kemandirian dan pertumbuhan tahun 2012 memperoleh bobot nilai 6,42 dengan predikat sangat tidak sehat. Namun, pada tahun 2013 dan 2014 memperoleh bobot nilai yang sama yaitu 23,54 dengan predikat tidak sehat (lihat tabel 3.11 halaman 38).

KPRI Sempulur menjadikan penilaian kesehatan koperasi berdasarkan Peraturan Menteri Koperasi dan UKM Nomor 14 Tahun 2009 sebagai tolok ukur penerapan akuntansi pertanggungjawaban dalam penilaian kinerja. Hasil penilaian kinerja kemudian dijadikan laporan pertanggungjawaban pengurus dan badan pengawas pada RAT. Hasil penelitian menunjukkan penilaian kesehatan KPRI Sempulur pada aspek permodalan pada tahun 2012 memperoleh nilai 35,91 dengan bobot34,28-42,85 predikat "Sehat". Pada tahun2013 memperoleh nilai 30,78 dengan bobot 25,71-34,28predikat "Cukup Sehat". Pada tahun 2014 memperoleh nilai 34,28dengan bobot34,28-42,85predikat "Sehat". Penilaian kesehatan pada aspek manajemen pada periode 2012 sampai 2014 memperoleh nilai 34,98 dengan bobot 34,28-42,85 predikat "Sehat". Penilaian kesehatan aspek kemandirian dan pertumbuhan koperasi pada tahun 2012 memperoleh nilai 6,24 dengan bobot 0-8,57 predikat "Sangat Tidak Sehat". Pada tahun 2013 dan 2014 memperoleh nilai 23,54 denganbobot 17,14-25,71 predikat "Kurang Sehat",hal ini disebabkan karena perbandingan SHU yang diperoleh dengan aset maupun modal sendiri masih terlalu tinggi. 


\section{SIMPULAN, KETERBATASAN, DAN SARAN}

Berdasarkan hasil dari keseluruhan perhitungan dan pembahasan dengan menggunakan Peraturan Menteri Negara Koperasi dan UKM Nomor14 Tahun 2009, dapat ditarik kesimpulan bahwa:

1. Penerapan akuntansi pertanggungjawaban dalam penilaian kinerja aspek permodalan pada KPRI Sempulur tahun 2012 dinyatakan sehat dengan nilai 35,91. Kinerja aspek permodalan tahun 2013 dinyatakan cukup sehat dengan nilai 30,78. Kinerja aspek permodalan tahun 2014 dinyatakan sehat dengan nilai 34,28 .

2. Penerapan akuntansi pertanggungjawaban dalam penilaian kinerja aspek manajemen pada KPRI Sempulur pada tahun 2012 hingga 2014 dinyatakan sehat dengan nilai 34,98 .

3. Penerapan akuntansi pertanggungjawaban dalam penilaian kinerja aspek kemandirian dan pertumbuhan pada KPRI Sempulur pada tahun 2012 sangat tidak sehat dengan nilai 6,24. Kinerja aspek kemandirian dan pertumbuhan tahun 2013 dan tahun 2014 dinyatakan kurang sehat dengan nilai 23,54.

Keterbatasan dalam penelitian ini adalah:

1. Penelitian ini, menggunakan wawancara dan pengamatan langsung dikantor KPRI Sempulur sehingga masih ada kemungkinan kelemahan-kelemahan yang ditemui, serta kurangnya kemampuan peneliti dalam menggali informasi.

2. Terkait dengan perizinan, peneliti hanya dapat meneliti satu objek koperasi yaitu KPRI Sempulur.

Berdasarkan simpulan dan keterbatasan dalam penelitian ini, maka saran yang diajukan dalam penelitian ini adalah:

1. Sebaiknya pihak KPRI Sempulur menambah karyawan yang mampu dalam bidang akuntansi, agar penyusunan laporan keuangan sesuai dengan standar akuntansi yang telah ditetapkan.

2. Lebih ditingkatkan lagi kemampuan karyawan dengan cara mengikut sertakan karyawan dalam pelatihan khususnya administrasi koperasi.

3. Pihak KPRI Sempulur harus berupaya meningkatkan SHU agar kemandirian dan pertumbuhan koperasi terus meningkat. 
4. Untuk peneliti selanjutnya agar bisa meneliti penilaian kinerja dengan semua aspek yang ada dalam Peraturan Menteri Negara Koperasi dan UKM Nomor 14 Tahun 2009.

\section{DAFTAR PUSTAKA}

Anthony, Robert N, Govindaran, Vijay. 2009.Sistem Pengendalian Manajemen. Jakarta: Salemba Empat.

Dinas Koperasi Kabupaten Magelang, www.magelangkab.go.id/index.php? view $=$ article $=$ aberita-perekonomian\&id-2014 [5> September 2014]

Era Masyarakat Ekonomi ASEAN, http://www.antaranews.com/berita/436319/ keisapan-koperasi-indonesia-menatap-era-mea-2015[4>September2014]

Gubernur terima Satyalencana, [Online] Didapatkan:www.Suara Merdeka. com/v1/index.php/read/cetak/2014/07/16/1267593/Gubernur-terima-satyalencana [15>Juli 2014]

Hansen Don R. Dan Maryanne M. Mowen. 2009. Akuntansi Manajerial.Jakarta:Salemba Empat.

Ikatan Akuntansi Indonesia. 2009. Standar Akuntansi Keuangan. Jakarta: Salemba Empat.

Indriantoro, Nur dan Bambang Supomo. 2002. Metedologi Penelitian Bisnis. Yogyakarta: BPFE. UGM.

Keiso Donald . Weygand. Jerry. J Paul D. Kimmel. 2008. Pengantar Akuntansi. Jakarta: Salemba Empat.

Lilik.2013. "Analisis Laporan Keuangan dalam Menilai Kinerja Keuangan pada Primer KoperasiAngkatan Darat Kartika Benteng Sejahtera" Jurnal Emba.(September), hal.46-71.

Misbachul dan Iin.2012. Analisis Tingkat Kesehatan Koperasi Simpan Pinjam Cendrawasih Kecamatan Gubug” Jurnal Emba. (Mei), hal 112-123.

Mulyadi.2004. Akuntansi Manajemen, Konsep, Manfaat dan Rekayasa. Edisi 2 Yogyakarta: STIE YKPN.

Mulyadi. 2006. Pengantar Akuntansi. Yogyakarta: STIE YKPN. 
Peraturan Menteri Negara Koperasi dan Usaha Kecil dan Menengah Republik Indonesia Nomor 20 Tahun 2008, tentang Pedoman Penilaian Kesehatan Koperasi Simpan Pinjam dan Unit Kopersi Simpan Pinjam.

Peraturan Menteri Negara Koperasi dan Usaha Kecil dan Menengah Republik Indonesia Nomor 14 Tahun 2009, tentang Pedoman Penilaian Kesehatan Koperasi Simpan Pinjam dan Unit Kopersi Simpan Pinjam.

Rifky. 2013. "Penerapan Akuntansi Pertanggungjawaban sebagai Alat Penilaian Kinerja Pusat Biaya pada PT Hutama Karya". Jurnal Emba. (September). Hal 314-325

Simamora, Henry. 1999. AkuntansiManajemen. Jakarta: SalembaEmpat.

Simanjuntak, Payaman. 2011. Manajemen dan Evaluasi Kinerja. Edisi ke 3. Jakarta: Fakultas Ekonomi Universitas Indonesia.

Sukarno, Edi. 2008. Sistem Pengendalian Manajemen Kinerja Konsep, Aplikasi dan Pengukuran Kinerja. Jakarta: PT. Indeks.

Sumarsan, Thomas, 2010. Sistem Pengendalian Manajemen. Konsep, Aplikasi, dan Pengukuran Kinerja. Jakarta: PT. Indeks.

Sunyoto, Danang. 2013. Metodologi Penelitian Akuntansi.Bandung: Refika Aditama. Undang-Undang Nomor 25 Tahun 1992 tentang Perkoperasian. 